\title{
ENTRE O LABOR ACADÊMICO E A CANDURA DO ENGAJAMENTO: O HIGIENISMO POR BOARINI ${ }^{1}$
}

\author{
Marcos Alexandre Gomes Nalli ${ }^{2}$ \\ Universidade Estadual de Londrina, Londrina-PR, Brasil
}

Os livros são objetos estranhos: multifacetados, de um ou vários autores, comportam todos e quaisquer assuntos. Podem se destinar a todo um público ávido seja lá pelo motivo que for - do conhecimento ou das frivolidades, assim como pode ficar relegado às prateleiras empoeiradas da indiferença e do esquecimento. De qualquer maneira, ao menos aqueles que se fazem imprescindíveis, nunca são fruto da frivolidade de seu(s) autor(es), e sim, sinais inequívocos e indeléveis de sua vida e de sua coerência. Os livros, neste sentido, são como que sinais do engajamento de quem os escreve, como bem afirma Sartre num fragmento de "O que é literatura".

Ter esta descrição - certamente um tanto poético-filosófica - do que são os livros é importante para começarmos a demarcar o mais novo livro organizado e encabeçado por Maria Lúcia Boarini, professora de Psicologia da Universidade Estadual de Maringá e líder do GEPHE - Grupo de Estudos e Pesquisa sobre Higienismo e Eugenismo - criado em 2000 no Diretório de Pesquisas do CNPq. Aliás, algumas palavras devem ser ditas sobre de Boarini. Quem a encontra pela primeira vez pode ter a impressão de estar diante de uma pessoa frágil e titubeante. Ledo engano. Mal sabe que está diante de uma batalhadora de frentes diversas, porém articuladas em sua vida - como não o dizer? - política, seja como professora ou como formadora de outros formadores, professores e pesquisadores, inicialmente no Curso de Mestrado em Fundamentos da Educação, e mais recentemente no Mestrado em Psicologia e na
Graduação em Psicologia, atuando sempre na Universidade Estadual de Maringá, Norte do Estado do Paraná, seja como psicóloga atuante no Movimento Antimanicomial e engajada em uma assistência à saúde, principalmente a mental, mais digna e justa, seja ainda à frente da edição da Revista Psicologia em Estudo, que fundou e da qual foi editora por praticamente uma década, entre 1996 e 2005. Isto para não mencionar outras tantas lutas em outras tantas frentes em que, a despeito de quaisquer agruras, sempre se empenhou com coragem, vigor e alegria contagiante.

A conjunção entre sua carreira acadêmica e seu envolvimento com as causas da saúde mental se faz notar pelo seu trabalho bibliográfico, notadamente nos livros que organizou e publicou. Além de inúmeros artigos e capítulos, Boarini publicou seis livros: Desafios na Atenção à Saúde Mental (2000 e 2011), Higiene e Raça como Projetos: Higienismo e eugenismo no Brasil (2003), Raça, Higiene Social e Nação Forte (2011), e Higiene Mental: Ideias que atravessaram o século XX (2012), dos quais foi organizadora; e A loucura no Leito de Procusto (2006), como autora, e Hiperatividade, Higiene Mental e Psicotrópicos: Enigmas da caixa de Pandora (2009), como coautora. Passemos agora a tecer alguns comentários sobre o último livro do qual é organizadora, Higiene Mental: ideias que atravessaram o século XX (2012), o qual certamente reflete a coerência de sua produção bibliográfica e de seu engajamento político como psicóloga profundamente atenta às questões e vicissitudes da Saúde Mental.

\footnotetext{
1 Apoio e financiamento: Conselho Nacional de Desenvolvimento Científico e Tecnológico (CNPq).

2 Endereço para correspondência: Rua Alexander Graham Bell, 433 - casa 36, Jd. Jamaica - CEP 86.063-250, Londrina-PR, Brasil. E-mail: marcosnalli@yahoo.com
} 
Exceto pelo prefácio, escrito por Alfredo Schechtman - médico e então membro da Coordenação de Saúde Mental do Ministério da Saúde (1991-2011) -, o livro é uma obra coletiva e feminina: provavelmente de um modo impensado e até imprevisto, todos os capítulos são escritos por mulheres, e certamente, ainda que possa soar como lugarcomum e chavão, todas as temáticas abordadas em Higiene Mental passam pelo crivo do olhar feminino, o que confere uma peculiaridade toda própria à natureza engajada do livro.

Se o tema geral do livro é a questão da higiene mental, ele é explorado estrategicamente a partir de alguns temas de base articulados entre si: o tema da infância, no capítulo escrito por Maria Lúcia Boarini - "A infância generalizada", no de autoria de Ednéia José Martins Zaniani - "Criminalidade infantil: a 'endemia traiçoeira' do Brasil republicano", no de Juliana Biazze Feitosa - "A institucionalização do adolescente autor de infração" - e no capítulo escrito em coautoria por Ednéia Zaniani e Susana Tomal Brondani "Prostitutas ou exploradas? Uma compreensão histórica acerca da exploração sexual comercial infanto-juvenil". Do ponto de vista temático, este último capítulo ocupa a posição de limiar para outro grande tema de base, que é a questão feminina e da família, em articulação com outros dois capítulos: o de Débora Kelly Herculano Machado Garcia - "O trabalho feminino nas telas e nas teias sociais" - e o de Renata Heller de Moura - "O encontro histórico entre família e programas de saúde pública". O texto de Renata Heller, por sua vez, faz também o papel de limiar temático, agora para a questão da profissionalização e da adoção de estratégias de ação e intervenção social, com vista a fazer jus ao ideário higienista. Inicia-se com a questão dos programas de saúde pública (analisados no capítulo mencionado) para, em seguida, considerar outras estratégias, como se nota nos capítulos de autoria de Roselânia Francisconi Borges - "A intersetorialidade através do tempo" - e de Lilian Denise Mai e Bruna Flávia Serafim Couto - "Capacitação e atuação profissional da enfermagem na perspectiva dos higienistas". O último grande tema que sustenta tematicamente o livro é a questão da drogadição e do alcoolismo, estudada no capítulo de Renata Cristina
Marques Bolonheis Ramos "O ideário higienista nas questões do álcool e outras drogas".

Obviamente, os textos do livro também apresentam outros fios de articulação entre si. A tese-mestra do livro já é exposta logo na apresentação escrita por Boarini. Há um incômodo generalizado entre as autoras de Higiene Mental: o de que fenômenos históricosociais são interpretados como naturais, de modo a serem objetivados, sendo-Ihes retirada a sua condição histórica própria e furtadas as suas condições sociais, eminentemente contraditórias. Como estas contradições não encerram em si nenhuma perspectiva causal reduzindo-se à condição fixa e atemporal sobre a qual as autoras do livro sempre alertam e que buscam evitar -, ao menos as condicionam e embasam, portanto também devem ser consideradas com o fito de desenhar um quadro mais amplo e heuristicamente concorde diante da complexidade dos fenômenos estudados. Ainda, em coerência com esta perspectiva não redutora, não se pretende, com esse livro, fornecer uma explicação exaustiva daqueles fenômenos, mas sim, com base no legado histórico de inúmeras páginas "amareladas pelo tempo", como diz Boarini (2012, p. 23), possibilitar uma reflexão mais ampliada e completa das temáticas referentes à higiene mental. Como ainda afirma a própria Boarini (2012) na apresentação do livro, "Mais do que simplesmente recontar os fatos passados, nosso compromisso ético-político enquanto pesquisadores é fomentar reflexões e, quiçá, superar aquelas explicações que nos paralisam, à medida que naturalizam a vida humana e as relações sociais" (p. 22).

Assim, vê-se bem o porquê de considerarmos engajado qualquer livro, neste caso específico, o livro Higiene Mental: ideias que atravessaram o século $X X$. Esta obra revela o que há de mais contundente na estirpe intelectual, profissional e política de Boarini: uma dedicação incansável e inquebrantável à causa da promoção da saúde psíquica das pessoas, com a convicção de que não se pode lutar por esta causa sem uma clara consciência de seus fatores e implicações histórico-sociais, os quais certamente contagiam todas as coautoras do livro e seus leitores, formando uma visão abrangente, perspicaz, contundente e instrutiva do ideário higienista, que como diz o 
livro em seu subtítulo, atravessaram de múltiplas maneiras o século XX.

\section{REFERÊNCIAS}

BOARINI, M. L. (Org.). (2012). Higiene Mental: Ideias que atravessaram o século XX. Maringá: EDUEM

Marcos Alexandre Gomes Nalli: doutor em Filosofia pela UNICAMP, pós-doutor pela EHESS (Paris), professor do Departamento e do Mestrado em Filosofia da Universidade Estadual de Londrina. 